\title{
Research Characteristics and Development Trend of Global Low-Carbon Power-Based on Bibliometric Analysis of 1983-2021
}

\author{
Xin-Cheng Meng ${ }^{1}\left(\mathbb{D}\right.$, Yeon-Ho Seong ${ }^{2}$ and Min-Kyu Lee ${ }^{3, *(D)}$ \\ 1 Graduate School of Management of Technology, Pukyong National University, 365 Sinseon-ro, Nam-gu, \\ Busan 48547, Korea; mengxincheng777@gmail.com \\ 2 Ocean Research Division, Korea Maritime Institute, 26 Haeyang-ro 301 Beon-gil, Yeongdo-gu, \\ Busan 49111, Korea; syh@kmi.re.kr \\ 3 Department of Industrial and Data Engineering, Major in Industrial Data Science \& Engineering, \\ Pukyong National University, 365 Sinseon-ro, Nam-gu, Busan 48547, Korea \\ * Correspondence: minkyu@pknu.ac.kr; Tel.: +82-51-629-5649
}

Citation: Meng, X.-C.; Seong, Y.-H.; Lee, M.-K. Research Characteristics and Development Trend of Global Low-Carbon Power-Based on Bibliometric Analysis of 1983-2021. Energies 2021, 14, 4983. https:// doi.org/10.3390/en14164983

Academic Editor:

Dimitrios Katsaprakakis

Received: 27 June 2021

Accepted: 11 August 2021

Published: 13 August 2021

Publisher's Note: MDPI stays neutral with regard to jurisdictional claims in published maps and institutional affiliations.

Copyright: (c) 2021 by the authors. Licensee MDPI, Basel, Switzerland. This article is an open access article distributed under the terms and conditions of the Creative Commons Attribution (CC BY) license (https:/ / creativecommons.org/licenses/by/ $4.0 /)$.

\begin{abstract}
Achieving Net zero emissions is a common challenge facing all mankind. Low-carbon electricity has always been the main research field of global GHG emission control. The current article aims to use the bibliometric analysis to describe the characteristics and trends of low-carbon electricity publications from 1983 to 2021 . We found that: (1) the number of publications in this area has shown an overall increase in the past 33 years. (2) the United States is the most powerful country in this field of research. Moreover, with the exception of major developed countries, more and more emerging economies have also joined the research on low-carbon power systems. (3) co-citation analysis and literature clustering characteristics show that the knowledge base in this field is focused on the decomposition of driving factors for carbon dioxide emissions and the optimization of the operation of renewable energy (RE) in low-carbon power systems. (4) the utilization of RE is a hot topic in low-carbon power research. Through this research, global scholars can be provided with the latest overview of valuable low-carbon energy research trends.
\end{abstract}

Keywords: low-carbon power; renewable energy; electrical energy storage; bibliometric analysis

\section{Introduction}

Slowing down the steady increase of global warming is a common challenge for nations across the world. More and more countries are strengthening their Nationally Determined Contribution by setting carbon neutralization targets. The target of the Paris Agreement, for example, is to "limit the increase in the global average temperature to less than $2{ }^{\circ} \mathrm{C}$ above pre-industrial levels and strive to limit the increase in temperature to $1.5^{\circ} \mathrm{C}$ above pre-industrial levels" [1]. The energy production and utilization industry is the world's biggest source of greenhouse gas (GHG) emissions. According to the BP world energy report, the power supply industry, especially fossil fuel power plants, is responsible for more than a third of global carbon dioxide $\left(\mathrm{CO}_{2}\right)$ emissions. Such power stations account for $64.2 \%$ of the world's electricity, and more than $70 \%$ of China's energy supply. Moreover, the International Energy Agency points out that the path toward controlling the global temperature at $1.5{ }^{\circ} \mathrm{C}$ and $2{ }^{\circ} \mathrm{C}$ shows that $\mathrm{CO}_{2}$ emission control in energy production would play an extremely important role in accomplishing the 2030 and 2050 climate goals [2]. Therefore, reducing the energy production sector's dependence on fossil fuels, expanding the ratio of renewable energy (RE) in primary energy consumption, and comprehensively considering the problem of power system adjustment brought by the low-carbon operation of the power sector have become key in accomplishing the global Net zero emission goal by the middle of this century [3]. 
Research on the power supply industry and carbon emissions can be traced back to the 1980s. Reister et al. [4] constructed a long-term global energy economic model to assess the problem of $\mathrm{CO}_{2}$ emissions from fossil fuels used in energy systems. Subsequently, scholars from the United States, the United Kingdom, the Netherlands, China, and other countries conducted many studies on the carbon emissions resultant from energy production activities from the perspectives of $\mathrm{CO}_{2}$ emission assessments and possible substitution with RE [5-8]. In 2003, a low-carbon economy was proposed for the first time in the Energy white paper 2003: our energy future - creating a low carbon economy of the British government. With the acceleration of global warming due to industrial activities, countries around the world started re-examining the urgency and arduousness of curbing climate change. More and more literature started focusing on the topics of energy efficiency and the advancement of low-carbon energy systems $[9,10]$. In the energy production sector, reducing $\mathrm{CO}_{2}$ is addressed from a technical perspective and the following directions are proposed: (1) improving the thermal conversion efficiency of fossil fuels; (2) developing an alternative to use non-fossil fuels; (3) $\mathrm{CO}_{2}$ capture and storage (CCS); (4) using RE or nuclear energy [11-13]. These studies focused on finding solutions to eliminate the negative effects of climate change generated by $\mathrm{CO}_{2}$ emissions from different areas of concern.

In recent years, the world's major developed countries and some developing countries have put forward Nationally Determined Contributions to control GHG emissions. In 2019, the British government legislated to achieve the Net zero emission target by 2050 , and the specific policies included continuing to expand the share of low-carbon electricity supply. The UK has thus become the first country in the world's major economies to establish this goal in legal form [14]. In 2019, Germany passed the Climate Protection Act, which for the first time legally determined that Germany would achieve Net zero emissions in 2050 [15]. China promised the world at the UN General Assembly in 2020 that it would strive to achieve the 2060 carbon neutralization target and would take effective measures to make the country's total carbon emissions peak by 2030 [16]. National level to control the emissions of greenhouse gases put forward the higher strategic goals, which is also reflected in the research trend of low-carbon power growth, the operation, and utilization efficiency of intermittent RE represented by solar and wind energy in the transformation of low-carbon power, and the economic, social, and technical feasibility study of power storage technology to guarantee the stability of power system operation. The construction of carbon trading market and the function of carbon tax policy in promoting the adjustment of energy structure has become a new research hotspot. It can be said that the global low-carbon power development research is moving towards the new goal of achieving global Net zero emissions.

At present, research perspectives related to low-carbon power development tend to be more diversified. In the context of sustainable development, research assumptions are made on economic growth, technological development, and lifestyle change, which are closely related to low-carbon power. For previous literature review articles, it is a challenge to effectively sort out the development trends and research frontiers in the research field, and to carry out quantitative analysis, especially for low-carbon power, an interdisciplinary research field that covers environmental science, energy science, and economics, especially the hot research area where the number of publications has expanded fast. With the help of bibliometric analysis methods, it is necessary to comprehensively and quantitatively review the progress of global low-carbon energy research and look forward to the frontier research trend, which will help scholars to make wise decisions on the focus of future research.

Under this background, through the method of bibliometric analysis, this paper comprehensively combs the literature related to low-carbon power collected on Scopus from 1983 to 2021, and visualized the development of the research literature in this field with the help of CiteSpace software. specifically, it expounds the characteristics of published publications from the fundamental features of the number of documents published and the three levels of the country, the publishing institution, and the author. In this paper, 
the research direction is analyzed by using the co-citation relation of literature and the occurrence frequency of key words. With a view to providing an up-to-date overview of global low-carbon energy research trends for researchers through the bibliometric research results.

The rest of the structure of the current study is organized as follows: Section 2 introduces the bibliometrics research methods, and introduces the data collection strategy and CiteSpace software. Section 3, starting from the statistical analysis of literature publication data, makes a detailed analysis of the publication characteristics from the macro (national), meso (journals), and micro (author) three levels. In Section 4, through co-citation analysis and keyword occurrence frequency, the knowledge base and the evolution trend of research hotspots in this field are analyzed. Section 5, the conclusion part, we summarize the main findings and summarize the limitations of the current study and future research recommendations.

\section{Methods and Data Collection}

\subsection{Bibliometric Analysis}

Bibliometrics are widely used in the quantitative analysis of scientific publications. It is an effective literature analysis method based on the identification of publications in a specific subject area [17]. Recent years saw a continuous improvement in the functions of visual literature analysis software, represented by CiteSpace and VOS viewer, as well as improvements of data quality in large citation databases. Therefore, the method of bibliometric analysis is being applied more and more. Bibliometric analyses have the following advantages:

- Quantitative analysis of target documents, objective measurement of research influence, and visual presentation with the help of visual graphs;

- Realizing the comparative analysis of large data sets;

- Analyses are scalable and can be performed at different levels of micro (author), meso (journal, institution), and macro (national) data sets [18,19].

Although some researchers have tried to use bibliometric analysis to study and analyze the research area of low-carbon energy, Wang et al. [20] adopted the bibliometric approach to analyze the characteristics of the literature on power system decarbonization from 1990 to 2016. Moreover, Yu et al. [21] investigated publications on low-carbon technology investment by using bibliometrics. However, due to the subtle differences in research periods and topics, especially the global average temperature control goal proposed by the Paris Agreement in 2015 and the consensus reached by all nations on the basis of the target of Net zero emissions by the second half of this century [22]. The new goal also brings an evolution in the research direction and research results and therefore, it is required to carry out a more expansive analysis of the development status and emerging trends in this field. Through this study, we hope to reveal the characteristics and trends of research on low-carbon development of energy production from the following perspectives:

- Is research on low-carbon still growing? (Based on the number of published articles);

- Who are the influential contributors to the field? (With regard to countries, journals, and authors);

- What are the hot spots and research frontiers of power system decarbonization research?

- What is the knowledge clustering of low-carbon energy production research based on keyword co-occurrence?

- What are the implications for the development of global low-carbon power?

\subsection{H-Index and SJR Factors}

H-index and SCImago Journal Rank (SJR) factors were used to describe the output performance of authors, countries/institutions, and journals related to decarbonization of energy production. The H-index means an evaluation index which considers the quantity 
and the quality of published literature; it is a valuable instrument for comparing the influence of different authors in specific fields. However, the H-index can simply gauge the influence of individuals and evaluate the influence of organizations and nations [23]. We measure the influence of journals and institutions using the SJR indicator. This index was devised by the SCImago research group and uses the Google algorithm PageRank to index Elsevier's Scopus database to evaluate scientific publications. This solution has several advantages, compared with the impact factor (IF) tool in the Journal Citation Report (JCR):

- The quality of the citation is considered using the PageRank algorithm; that is, each citation is weighted according to the reputation of the citation journal;

- $\quad$ The coverage of the Scopus database is wider than that of the JCR [24].

It should be noted that the $\mathrm{H}$-index and SJR factors used in this study to evaluate the relative importance of countries, research institutions, and journals are based on the latest data released by Scimago Lab in 2019.

\subsection{CiteSpace}

This study also used CiteSpace software, developed by Chaomei Chen, for scientific metrological analysis and the visual processing of literature data. CiteSpace can effectively map knowledge by analyzing the structure and time of various social networks of scientific publications, including national collaboration network, author co-citation network, and keyword co-occurrence network. The relevant literature provides more information on how to use the CiteSpace software to conduct scientometrics in the research field [25].

\subsection{Data Sources}

We collected data from Elsevier's Scopus database. Scopus was started in 2004 and, compared with Clarivate Analytics' Web of Science database, it offers a much broader range [24], currently covering approximately 34,000 scientific publications from around 7000 publishers. Therefore, more extensive bibliometrics and historical trend analyses can be performed. Scopus also adopts a more rigorous expert review system and an improved $\mathrm{H}$-index measure, based on authors; therefore, the inclusion of research results is more representative of the discipline.

Before effective data retrieval, we determine the research boundaries to obtain citation data more effectively. The target of the current study is to explore the contribution of the global academic community to research on decreasing carbon emissions in power systems (especially in the electricity production sector); therefore, we limit the research sector to power systems or energy systems. At present, the key words in the field of low-carbon emission of power systems mainly focus on "Low Carbon Development" (LCD) and "Low Carbon Transition" (LCT). We should mention that there is no clear academic definition of LCD and LCT in the research field, and they are often substituted for each other in academic literature and policy documents. By reviewing the relevant literature, we discover that most of the statements about LCD focus on integrating carbon reduction strategies into the current economic development path [26,27], Urban and Nordensvar [28] define it as a development model that is driven towards growth by methods aimed at reducing carbon emissions (e.g., shift to RE and promote carbon sink). LCT, however, incorporates the concept of low-carbon into a more systematic and long-term concept. Geels et al. [29] describe it as a major change in the energy system from fossil fuel use to RE replacement, involving technological change, social consensus, and mechanism innovation. Typically, it is used to check for transitions in specific sectors, such as power and heat [30]. To obtain more comprehensive citation data, we only select "low-carbon" or "low carbon" as keywords for retrieval to maximize the retrieval scope. More and more countries have started to announce its carbon neutral status, and research has started paying special attention to the increasing number of countries with carbon neutral goal setting and the demand for low carbon transformation and opportunities; however, it seldom appears in existing studies. To include this subject in our study on LCD trends, we included "carbon neutral" and "carbon emission" in the search terms. Finally, the retrieval policy was set to: 
TITLE-ABS-KEY (["low carbon" OR "low-carbon" OR "Carbon neutral" OR "Carbon emission"] AND ["energy system" OR "power system" OR "electricity" OR "Electric power"]).

On 1 May 2021, 6426 initial literature records were extracted from the online library of Pukyong National University, South Korea. The retrieval data were further screened and the literature type was limited to "Article-ar," the publication source type was limited to "SRCTYPE-j," the category was limited to Energy and Environmental Sciences "SUBJAREA-ENER, ENVI," and literature that was not relevant to the research topic was manually deleted after reading the title and abstract. In the end, 1431 documents were obtained, covering the period 1983-2021. The complete records and metadata referenced were downloaded and imported into CiteSpace for data cleansing and analysis. After reprocessing by CiteSpace software, 1419 valid literature records were finally obtained. The overall research framework is shown in Figure 1.

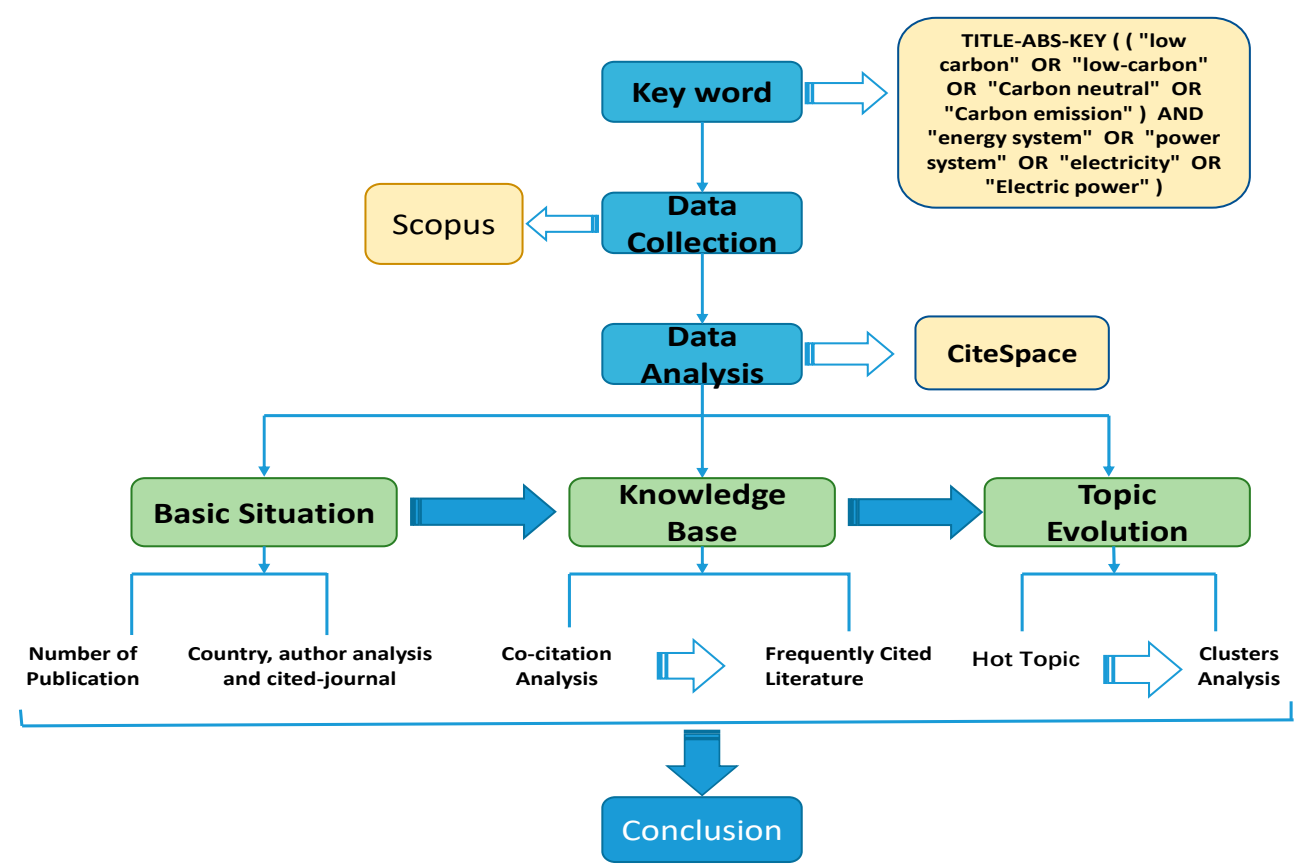

Figure 1. Research framework.

\section{Results and Discussion}

\subsection{Literature Quantity Analysis}

The number of publications in the current study area has generally expanded during the past 33 years. However, after the enactment of the Paris Agreement in 2015, the number of papers published in this research field has increased tremendously, with 205 published in the first four months of 2021 alone; moreover, the number of publications for the entire year is likely to reach an all-time high. Such trend mirrors the increasing attention in the subject on a global scale. The number of publications on the subject, from 1983 to 2021, can be seen in Figure 2.

\subsection{Analysis of Country, Cited Journal, and Author}

To illustrate the research status quo of low carbon transformation in energy systems, this section presents a visualization based on CiteSpace and the total lead relationships, the development procedure, and the composition of scientific knowledge in the field. Using these inputs, we identify countries with the greatest influence and forefront achievement in this field, as well as journals and authors who set out to acquire scientific knowledge of the different elements involved in the research area. 


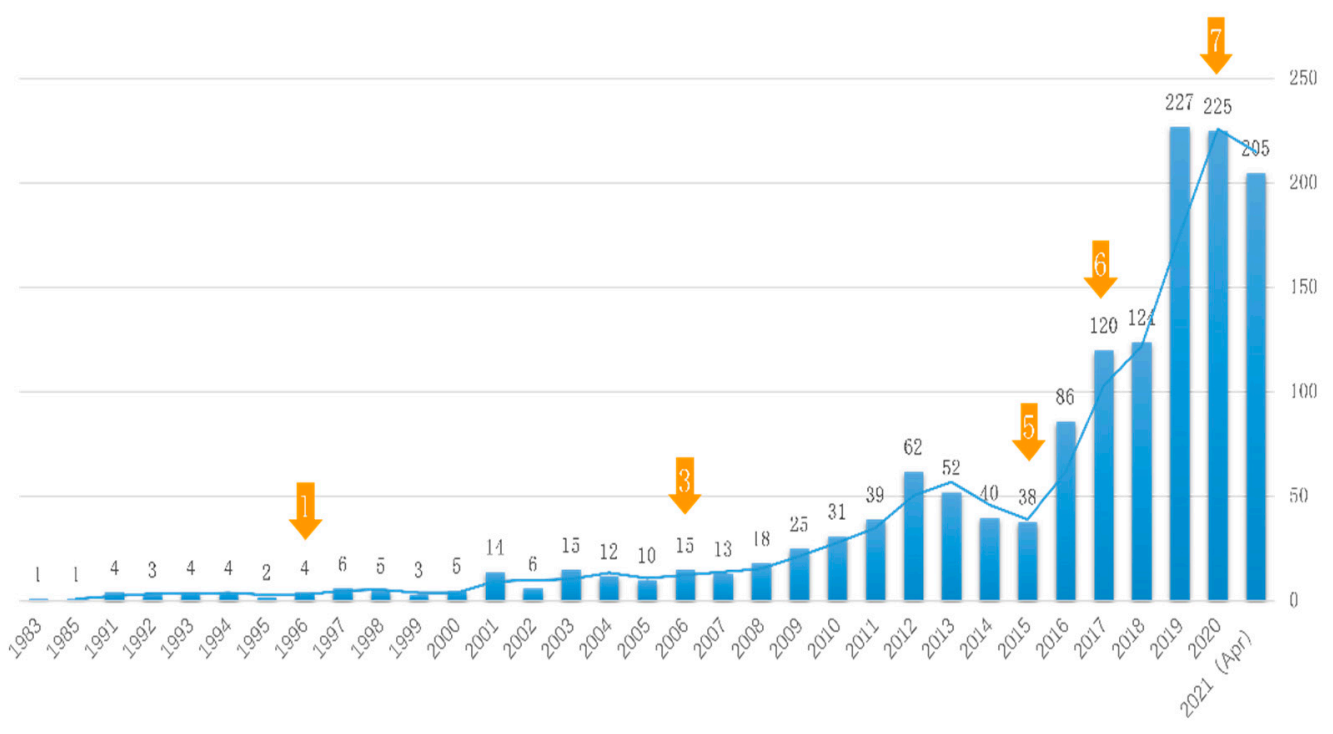

Figure 2. Number of publications on low-carbon energy production from 1983 to 2021 by year.

\subsubsection{Country Productivity}

Table 1 lists the publications of the top 10 research-producing countries and lists the $\mathrm{H}$-index of the Environmental Science and Energy category, respectively, according to the main distribution fields of low-carbon energy production literature. The graph network in Figure 3 is used to describe the academic productivity and influence of countries or regions. In the network graph, Citation tree-rings are used to describe the citation history of the node, with the different colors of tree-rings representing the citation times and the thickness of the rings indicating the number of citations of the node. The thickness of the citation tree-ring has a positive relationship with the number of citations in the node. Betweenness centrality is an important indicator that shows boundary-spanning potentials and novel brokerage connections among scholarly publications in CiteSpace [24]. Nodes with higher betweenness centrality are shown as purple rings. The thickness of the purple rings shows the value of betweenness centrality, which is used to describe the importance or influence of this node on other nodes in the network.

Table 1. Top 10 productive countries for the period 1983-2021.

\begin{tabular}{cccccc}
\hline Country & TC & First Year & $\begin{array}{c}\text { Betweenness } \\
\text { Centrality }\end{array}$ & $\begin{array}{c}\text { H-Index } \\
\text { Environmental } \\
\text { Science }\end{array}$ & Energy \\
\hline CHINA & 1054 & 1991 & 0.09 & 368 & 333 \\
UNITED STATES & 989 & 1983 & 0.9 & 691 & 454 \\
UNITED KINGDOM & 733 & 1992 & 0.03 & 480 & 291 \\
GERMANY & 508 & 1997 & 0.19 & 404 & 266 \\
THE NETHERLANDS & 279 & 1991 & 0 & 367 & 214 \\
AUSTRALIA & 264 & 2003 & 0.01 & 367 & 241 \\
ITALY & 262 & 1996 & 0.1 & 298 & 204 \\
JAPAN & 260 & 2002 & 0.01 & 280 & 261 \\
AUSTRIA & 259 & 1991 & 0.06 & 229 & 130 \\
CANADA & 251 & 2001 & 0.05 & 381 & 278 \\
\hline
\end{tabular}




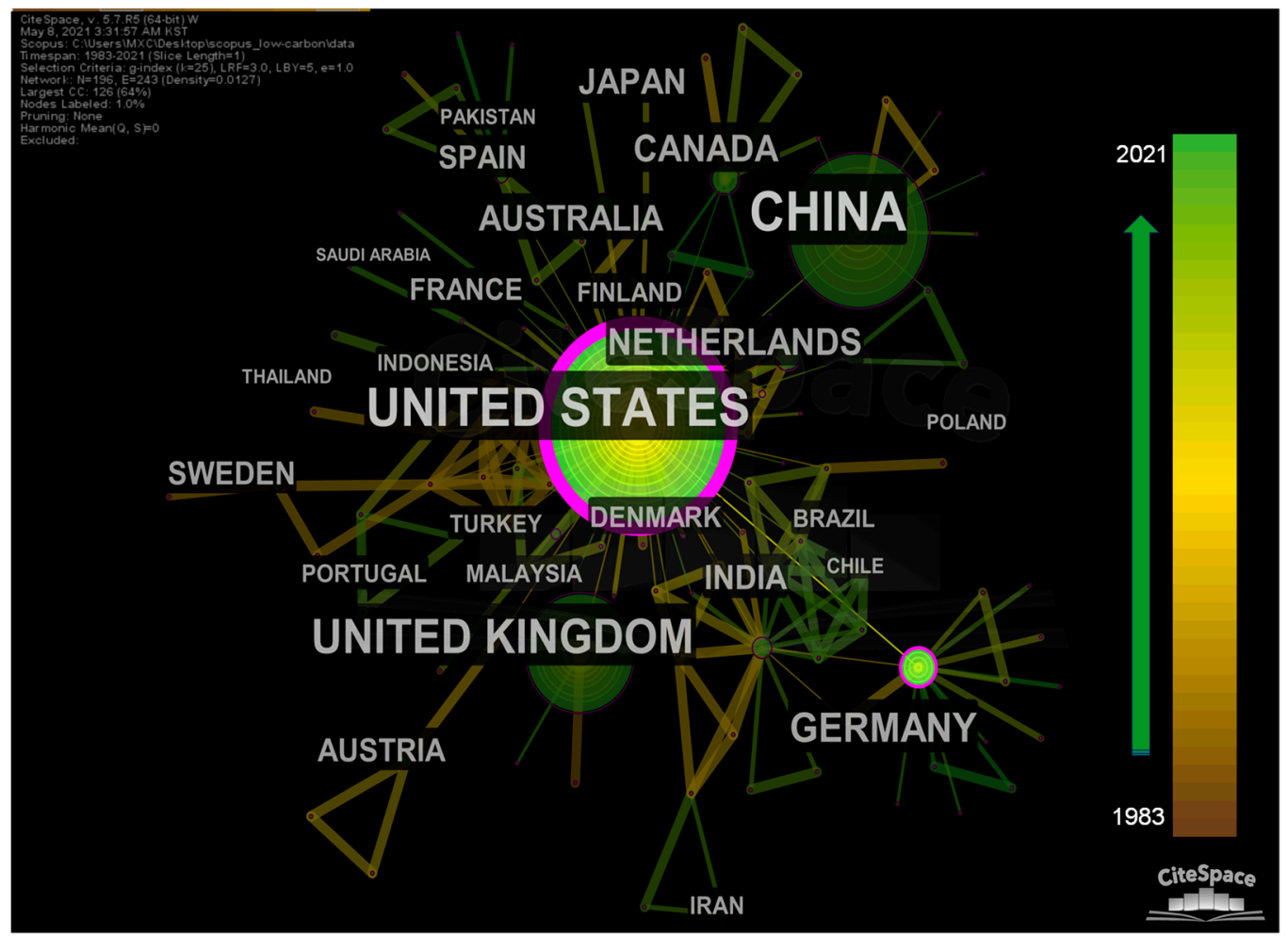

Figure 3. National cooperation network map, 1983-2021.

From 1983 to 2021, a total of 1419 papers from 77 countries have contributed to the research area of low-carbon energy systems. The ten most active countries or regions were China, the United States, the United Kingdom, Germany, the Netherlands, Australia, Italy, Austria, Japan, and Canada. Regarding the start of research in this area, the United States was the first to conduct research on this subject (1983), with China, Austria, and the Netherlands starting to conduct research regarding $\mathrm{CO}_{2}$ discharges from power systems in 1991. From the perspective of intermediary centrality, the United States (0.9) and Germany (0.19) have a strong influence in this research field and have established close international relationships with other countries.

Considering the total number of publications, China and the United States are the two most productive countries. The reason for this is that in 2006, China first published the government work target of energy conservation and discharge mitigation in its 11th Five-Year Plan. Since then, China's academic productivity in this field has been increasing. Of the total of 202 scientific publications in 2020, China contributed 90 publications. Among them, the number of international cooperative publications and independent publications accounted for $50 \%$. As the biggest developed country in the world, the United States is facing great pressure to reduce carbon emissions. Europe has been a strong advocate of reducing carbon emissions, accounting for 50\% of the top 10 productive countries. Moreover, European countries generally started their research on carbon emission reduction earlier and their robust scientific research strength is not only reflected in their productivity, but also in their academic influence. As can be seen in Figure 3, European countries occupy a relatively central position in the network map and have been part of extensive academic cooperation with other countries.

We also noticed that, with developing countries' increasing concern about climate change adaptation and environmental protection, there are positive changes in the number of publications. For example, there are ten developing countries in the top 30 productive countries list. As can be seen in Figure 3, except for China and India, developing countries such as Pakistan, Thailand, Indonesia, Iran, and Malaysia are also gradually starting to contribute to their research strength in this field through international cooperation. To 
some degree, the distribution of publications in this field mirrors the general situation of different countries in academia [21].

\subsubsection{Author Productivity}

There are 5313 authors who have contributed to the research on low-carbon energy production. We focused more on the top ten authors-those with the highest productivity, as shown in Table 2-by starting time of research in this field. The H-index helps us to discover the academic influence and research topic distribution of the most productive authors.

Table 2. Ten most productive authors, 1983-2021.

\begin{tabular}{cccccc}
\hline Author & Institution & Country & TC & H-Index & First Year \\
\hline Lin, Boqiang & Xiamen University & China & 13 & 62 & 2014 \\
\hline Kang, Chongqing & Tsinghua University & China & 10 & 55 & 2009 \\
\hline Wei, Yiming & Beijing Institute of Technology & China & 9 & 62 & 2009 \\
\hline Yuan, Jiahai & North China Electric Power & China & 9 & 27 & 2011 \\
\hline $\begin{array}{c}\text { Van Vuuren, Detlef } \\
\text { P. }\end{array}$ & $\begin{array}{c}\text { PBL Netherlands Environmental } \\
\text { Assessment Agency }\end{array}$ & The Netherlands & 8 & 85 & 2003 \\
\hline Ang, Beng Wah & National University of Singapore & Singapore & 8 & 66 & 2002 \\
\hline $\begin{array}{c}\text { Sovacool, Benjamin } \\
\text { K. }\end{array}$ & Aarhus Universitet & Denmark & 8 & 64 & 2015 \\
\hline Luderer, Gunnar & Leibniz-Gemeinschaft & Germany & 8 & 47 & 2011 \\
\hline Chen, Wenying & Tsinghua University & China & 8 & 22 & 2013 \\
\hline Masui, Toshihiko & $\begin{array}{c}\text { National Institute of } \\
\text { Environmental Studies of Japan }\end{array}$ & Japan & 7 & 42 & 2012
\end{tabular}

Of the top ten authors with the highest productivity, five are from China. This result is related to the selection of research fields in this study. In China, 70\% of the power supply structure is thermal power generation and high fossil energy consumption produces a large volume of $\mathrm{CO}_{2}$ emissions. The development of China's power system during the next decade will therefore be critical to its goal of peaking by 2030 and being carbon neutral by 2060 or earlier [3]. How to build an energy structure dominated by RE, as well as the resulting energy efficiency, energy storage efficiency, and policy selection of carbon market trading are research directions that Chinese scholars have been focusing on recently [31-34]. China's research output is excellent in terms of national productivity and author productivity; however, its impact on global research trends is more limited, due to its high output and low citation rates.

Authors and studies with high citation frequency are often important nodes of research topics and research frontiers in this field. This study explored the top ten most highly cited authors and papers; these are presented in Table 3. Ang and Su [35] started a study on carbon emissions in 2002. Their main research focuses on the Energy Intensity and Logarithmic Mean Divisia Index (LMDI). They employed the LMDI approach to explore the total carbon intensity (ACI) change in terms of energy production in the world. It is noted that the progress of thermal efficiency in energy production plays a leading role in the primary impetus for ACI reduction. Their research topics also include structural decomposition analysis (SDA). For example, the index decomposition analysis (IDA) and SDA methods are utilized to evaluate the driving components of energy use and emissions in economic activities [36]. 
Table 3. Top 15 most influential journals, 1983-2021.

\begin{tabular}{|c|c|c|c|c|c|c|c|}
\hline Journal & $\mathrm{NP}^{1}$ & $\mathrm{CCP}^{2}$ & $\mathrm{NP} / \mathrm{CCP}$ & $\mathrm{SJR}^{3}$ & H-Index 4 & Country & Publication \\
\hline Nature Energy & 9 & 763 & 84.77 & 19.635 & 92 & United States & Springer Nature \\
\hline $\begin{array}{c}\text { Energy and } \\
\text { Environmental Science }\end{array}$ & 5 & 318 & 63.6 & 13.024 & 311 & United Kingdom & $\begin{array}{l}\text { Royal Society of } \\
\text { Chemistry }\end{array}$ \\
\hline $\begin{array}{c}\text { International Journal of } \\
\text { Hydrogen Energy }\end{array}$ & 11 & 609 & 55.36 & 1.141 & 202 & United Kingdom & Elsevier Ltd. \\
\hline Applied Energy & 166 & 6824 & 41.11 & 3.607 & 189 & United Kingdom & Elsevier BV \\
\hline Energy Policy & 342 & 13,236 & 38.7 & 2.168 & 197 & United Kingdom & Elsevier BV \\
\hline Renewable Energy & 33 & 1124 & 34.06 & 2.052 & 174 & United Kingdom & Elsevier BV \\
\hline $\begin{array}{c}\text { Environmental Science } \\
\text { and Technology }\end{array}$ & 16 & 486 & 30.37 & 2.704 & 373 & United States & $\begin{array}{c}\text { American } \\
\text { Chemical Society }\end{array}$ \\
\hline Energy Economics & 64 & 1827 & 28.55 & 2.409 & 136 & The Netherlands & Elsevier \\
\hline $\begin{array}{l}\text { IEEE Transactions on } \\
\text { Power Systems }\end{array}$ & 10 & 254 & 25.4 & 3.434 & 242 & United States & $\begin{array}{l}\text { Institute of } \\
\text { Electrical and } \\
\text { Electronics } \\
\text { Engineers }\end{array}$ \\
\hline Energy & 145 & 2456 & 22.33 & 2.166 & 173 & United Kingdom & Elsevier Ltd. \\
\hline $\begin{array}{l}\text { International Journal of } \\
\text { Greenhouse Gas Control }\end{array}$ & 20 & 426 & 21.3 & 1.131 & 107 & Netherlands & Elsevier \\
\hline $\begin{array}{l}\text { Journal of Cleaner } \\
\text { Production }\end{array}$ & 79 & 1296 & 16.4 & 1.886 & 173 & Netherlands & Elsevier Ltd. \\
\hline $\begin{array}{l}\text { Science of the Total } \\
\text { Environment }\end{array}$ & 21 & 283 & 13.47 & 1.661 & 224 & Netherlands & Elsevier \\
\hline $\begin{array}{c}\text { Renewable and } \\
\text { Sustainable Energy } \\
\text { Reviews }\end{array}$ & 21 & 254 & 12.09 & 3.632 & 258 & Netherlands & Elsevier Ltd. \\
\hline Energies & 37 & 286 & 7.72 & 0.635 & 78 & Switzerland & MDPI \\
\hline
\end{tabular}

${ }^{1} \mathrm{NP}$ is number of publications per journal. ${ }^{2} \mathrm{CCP}$ is citations per publication. ${ }^{3} \mathrm{SJR}$ is SCImago Journal Rank (SJR) indicator and data source is https:/ / www.scimagojr.com/index.php (accessed on 5 May 2021). ${ }^{4}$ H-index source is https:/ / www.scimagojr.com/index.php (accessed on 5 May 2021).

Van Vuuren, as an influential author (H-Index: 85), started studying carbon emissions in 2003. In recent years, their main research direction has been focused on the Integrated Assessment Model. In terms of climate policy and the global temperature increase, 81 relevant studies have contributed to the scenario analysis of climate change and the cost model of $\mathrm{CO}_{2}$ emissions $[37,38]$.

Several other high-productivity scholars have also focused on comprehensive climate change assessment models, energy efficiency, energy transition, and other aspects of their research, from macro to micro perspectives. In terms of energy efficiency and energy planning, energy efficiency and strict early cuts become significant to maintain the probability of restricting global warming to below $1.5^{\circ} \mathrm{C}$ by 2100 [39]. Moreover, in Ren and Sovacool's [40] work, an Analytic Hierarchy Process was used to evaluate several low-carbon energy sources with regard to the energy security; the conclusion was that hydroelectricity energy were the most likely low-carbon alternative to increase China's energy safe measures. Toshihiko employed a computable general equilibrium model to study the impact, cost, and common benefits of the low-carbon strategy of the power industry in China, on its energy and $\mathrm{CO}_{2}$ discharge goals in 2020 [41]. 


\subsubsection{Distribution of Journals}

The statistical results of the journal sources show that the 1419 articles on low-carbon energy production research were published in 143 journals. Table 3 specifies the top 15 peer-reviewed journals by journal impact factor. In addition to considering the number of publications, we also refer to SJR and the $\mathrm{H}$-index for the ranking of the journal influence. Some journals have a limited number of publications due to their late start; despite this, they have become important influential journals in this field, due to their high-quality publications and high citation rate. Examples are Nature Energy (2016) and Energy and Environmental Science (2008). The total number of publications in the top 15 journals is 979, accounting for $68.99 \%$ of the total number of publications. This indicates that publications in low-carbon energy production research are concentrated in these top journals. Energy Policy is the most productive journal with 342 publication records, followed by Applied Energy (166) and Energy (145). According to the SJR metrics, Nature Energy (19.635) ranked first, followed by Energy and Environmental Science (13.024). Other journals' SJR values were similar, indicating that all these journals are influential in terms of low-carbon energy research.

The key journals in the research field can be screened macroscopically, based on the statistical data and SJR indicators. At a micro level, the citation relationship between documents is an interrelated and expanding system. Through CiteSpace, the citation network of periodical publications in recent years (2015-2021) and the citation network of periodical publications for the entire research period (1983-2021) are analyzed by Overlay to determine the journal sources of recent research hotspots and interpret the core journals from a different perspective. In Figure 4, the red line shows the source path of the citation literature in the most recent year, the radius of the node is positively correlated with the total number of citations in the most recent year, and the red circle in the node indicates the sudden increase in the frequency of the node in the selected time series; this is used to describe the surge in the number of journals cited. It is clear that Energy Policy and Energy are the top two journals with the most citations from 2015 to 2021, while Nature Energy publications are always cited with a low frequency, but with a strong burst, and with the attention increasing continuously in recent years.

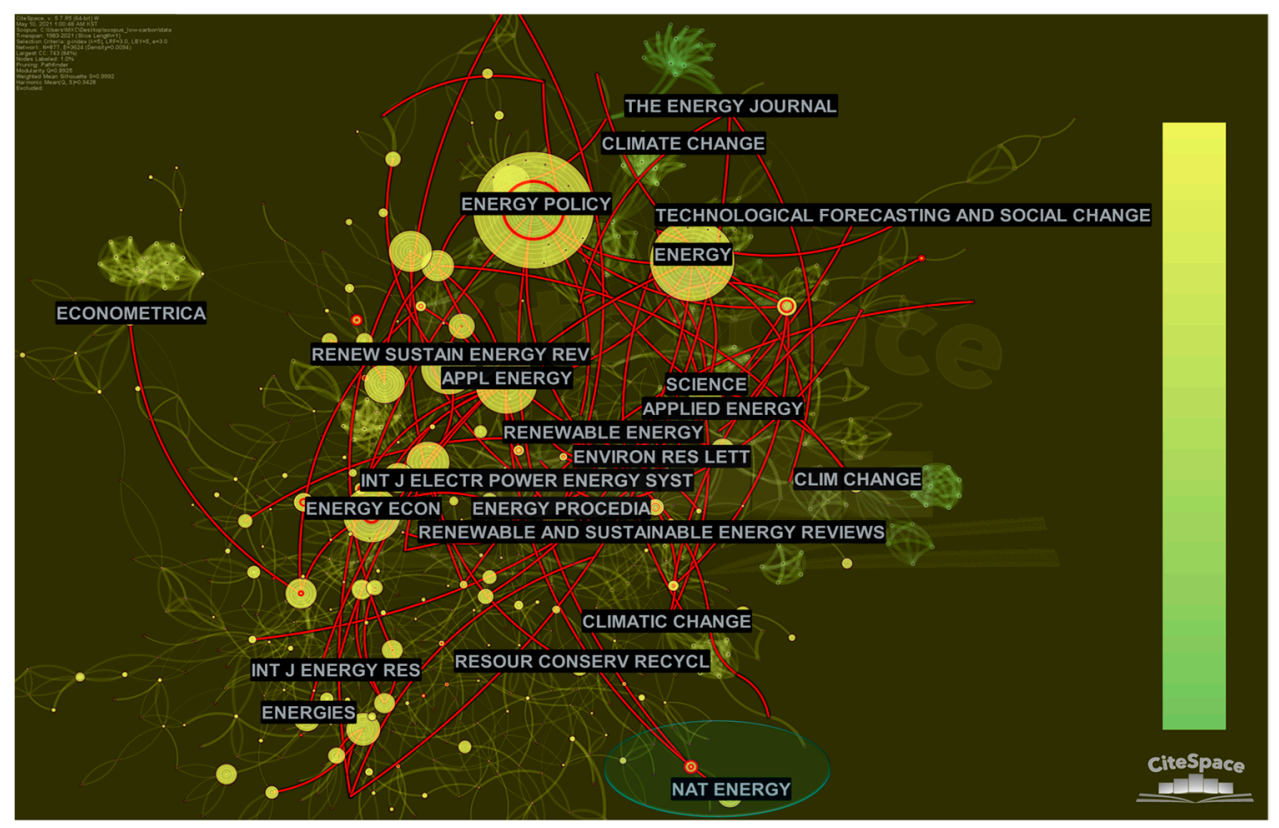

Figure 4. 2015-2021 key cited journal network overlay map during 1983-2021. 
This finding is also in agreement with the data presented in Table 4. Nature Energy was founded in 2016 and its SJR index surged to 19.635 in just five years, indicating that the journal reflects a high level of publication quality.

Table 4. Top 10 highly cited papers based on co-citation analysis of references.

\begin{tabular}{|c|c|c|c|c|}
\hline $\begin{array}{l}\text { Cited } \\
\text { Frequency }\end{array}$ & Author & Cited reference & Centrality & Year \\
\hline 24 & Ang, Beng Wah & $\begin{array}{c}\text { Carbon emission intensity in } \\
\text { electricity production: A global } \\
\text { analysis }\end{array}$ & 0.02 & 2016 \\
\hline 24 & Ang, Beng Wah & $\begin{array}{l}\text { LMDI decomposition approach: A } \\
\text { guide for implementation }\end{array}$ & 0.01 & 2015 \\
\hline 19 & Lund, Peter D. & $\begin{array}{l}\text { Review of energy system flexibility } \\
\text { measures to enable high levels of } \\
\text { variable renewable electricity }\end{array}$ & 0.04 & 2015 \\
\hline 17 & Liu, Zhu & $\begin{array}{l}\text { Reduced carbon emission estimates } \\
\text { from fossil fuel combustion and } \\
\text { cement production in China }\end{array}$ & 0.02 & 2015 \\
\hline 13 & $\begin{array}{l}\text { Brouwer, Anne } \\
\text { Sjoerd }\end{array}$ & $\begin{array}{l}\text { Least-cost options for integrating } \\
\text { intermittent renewables in } \\
\text { low-carbon power systems }\end{array}$ & 0.04 & 2016 \\
\hline 13 & $\begin{array}{l}\text { Pfenninger, } \\
\text { Stefan }\end{array}$ & $\begin{array}{l}\text { Long-term patterns of European PV } \\
\text { output using } 30 \text { years of validated } \\
\text { hourly reanalysis and satellite data }\end{array}$ & 0.01 & 2016 \\
\hline 12 & Wang, H. & $\begin{array}{c}\text { Assessing drivers of economy-wide } \\
\text { energy use and emissions: IDA } \\
\text { versus SDA }\end{array}$ & 0 & 2017 \\
\hline 11 & $\begin{array}{l}\text { Karmellos, } \\
\text { Marios }\end{array}$ & $\begin{array}{l}\text { A decomposition analysis of the } \\
\text { driving factors of } \mathrm{CO}_{2} \text { (Carbon } \\
\text { dioxide) emissions from the power } \\
\text { sector in European Union countries }\end{array}$ & 0.02 & 2016 \\
\hline 11 & Staffell, Iain & $\begin{array}{l}\text { Using bias-corrected reanalysis to } \\
\text { simulate current and future wind } \\
\text { power output }\end{array}$ & 0.01 & 2016 \\
\hline 10 & Cheng, Rui & $\begin{array}{c}\text { A multi-region optimization } \\
\text { planning model for China's power } \\
\text { sector }\end{array}$ & 0.02 & 2015 \\
\hline
\end{tabular}

\section{Research Hotspots and Trends}

\subsection{Knowledge Base}

A co-citation analysis means an approach that measures the frequency of two articles being cited simultaneously when considering the main papers in the database. When two papers show a strong relationship, that is, if they are often cited together, they must also be cited separately [42]. The co-citation analysis helps us to find innovative and high-quality literature, which is also the knowledge base of this research field, and provides the most valuable reference knowledge for researchers [43]. The top ten co-cited literature networks generated in CiteSpace reflect the trend of the flow and evolution of the knowledge base in this field (Table 4).

Wang et al. [44] and Ang [45] report the latest progress of IDA, SDA, and LMDI decomposition models in studying the factors of energy consumption and changes in energy emissions. These are widely used in energy and climate policy assessment and development and have become widely accepted analytical tools for policy formulation on national energy and environmental issues. This has also been used in the literature of Ang and Su [35], who use LMDI decomposition models to explore the ACI change of 
total carbon intensity of electric power across the globe. Karmellos et al. [46] and Yang and Lin [47] use LMDI to decompose the power industry indicators of Europe and China, respectively, and obtain similar results: electric intensity, economic operation, and energy efficiency are the principal elements of increased carbon discharges.

Liu et al. [48] adopts a method for calculating "apparent consumption" based on the material balance of domestic fuel production, global trade, international fuel, and inventory changes, distinguishes the different emission elements of imported fuel and domestic fuel according to the coal source, and reassesses China's carbon emissions. Their study provides a new way of accurately estimating emissions by countries or regions and production departments.

Lund et al. [49] investigated flexible measures to ensure the stability of the energy system; they point out that many types of RE with variable characteristics connected to the power system may lead to a lag in response to power system load changes, resulting in potential system security risks. In general, there is a wide range of options for flexibility measures in power systems. Among them, demand side management realizes peak cutting, valley filling, and load transfer within the power system by affecting the terminal energy consumption mode and energy consumption time. Further, power grid auxiliary services provided through energy storage technology also increase the elasticity of the power system to some extent; however, an adverse cost impact on energy storage due to price perversion (grid costs and shortage of price transparency) should be avoided [50-53].

Pfenninger and Staffell [54] introduce a new method to simulate the operation of photovoltaic power generation, according to meteorological reanalysis and satellite measurement data. Their work is very important in terms of improved understanding of the impact of intermittent RE—-such as photovoltaics and wind energy — on the grid and determining technical and economic strategies such as energy storage capacity. Staffell and Pfenninger [55] use this method to simulate the efficiency of wind energy output, pointing out that "national correction factors" should be introduced according to different spatial locations.

From the perspective of the lowest cost choice, Brouwer et al. [56] simulate the integration cost of RE with different permeability in the power system, although there are many research limitations. Cheng et al. [57] propose a regional optimization model considering the regional differences of resource availability and inter-regional transmission line capacity to support the investment decisions of China's power sector.

The co-citation analysis results show that CiteSpace software was used to divide the relevant works into five clusters to show the low-carbon energy production research field's segmentation in detail, as shown in Figure 5. Cluster analyses are often used to identify and analyze the classification of significant terms and backgrounds in specific research areas and to conduct exploratory data mining on research topics. Co-citation analyses of literature can help researchers to immediately obtain the most valuable references, while a cluster analysis provides them with valuable research specifications, as the content of the publications in the same cluster are alike. Documents with the same characteristics are clustered by extracting the keyword tags from the literature, and the relationship between the documents is proved [43].

The \#0 cluster, labeled "Electricity Generation" is the largest and contains 103 publications. This cluster describes the general situation of low-carbon electricity production. Decreasing $\mathrm{CO}_{2}$ emissions in the power section is a fundamental component of any lowcarbon energy transition strategy [58]. Intense decarbonization of the power section will be achieved through high diffusion of RE resources (e.g., wind, photovoltaics, and hydropower) [9]. However, it is necessary to contemplate the increase in environmental impacts and economic indicators of the power sector as well as social costs $[59,60]$. Some studies have shown that, to reduce $\mathrm{CO}_{2}$ emissions in power systems, two mitigation schemes need to be considered at the same time: (1) intermittent RE sources and an energy storage technology cooperation scheme, and (2) increasing the CCS capacity of thermal power plants. These measures will help to reduce the increase in social costs caused by 
the implementation of emission reduction targets $[56,61,62]$. At the same time, we should also be aware that a delay of decarbonization action in the power system will lead to a significant increase in decarbonization cost [63].

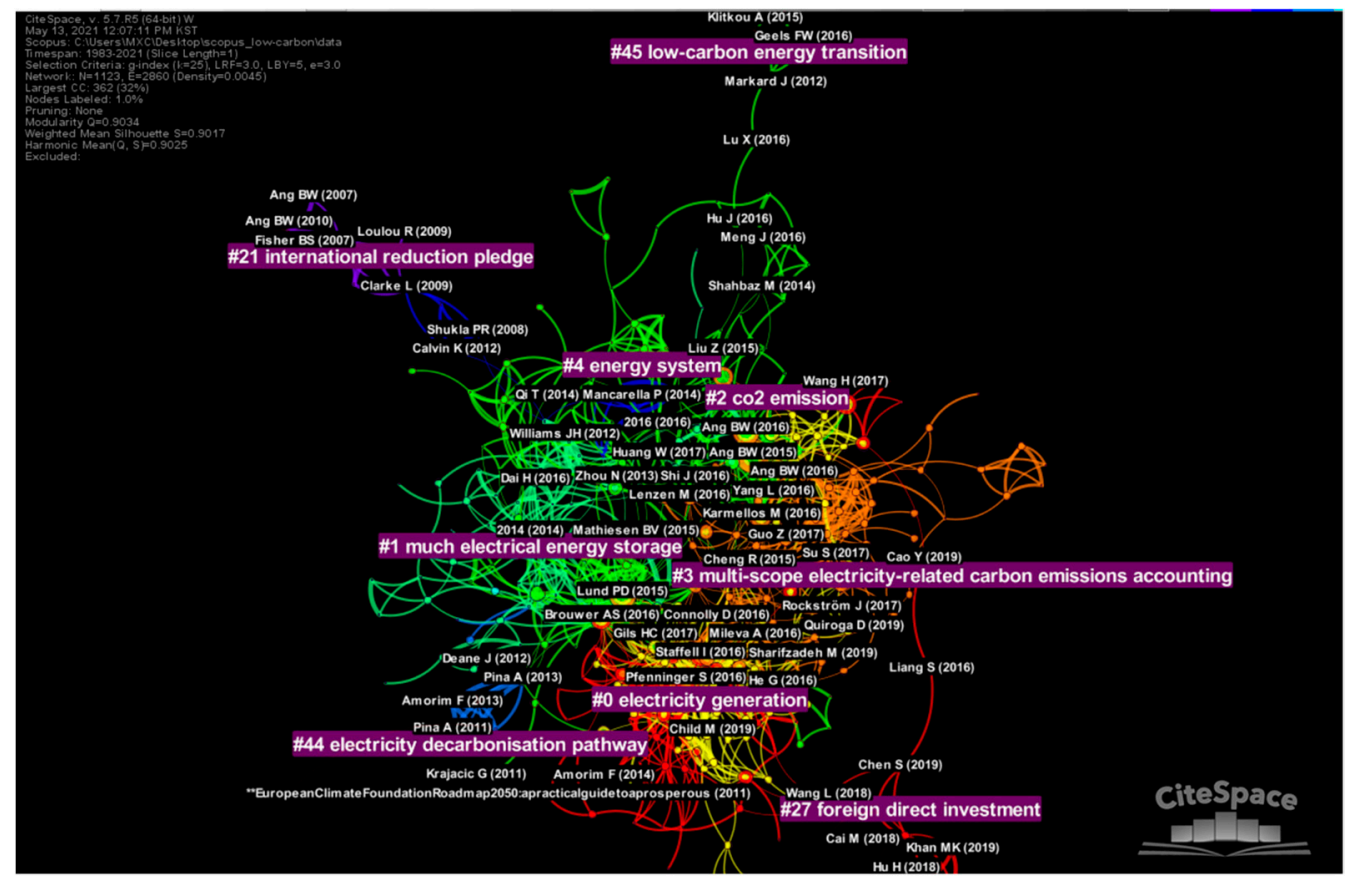

Figure 5. Co-citation cluster analysis.

The subject "much electrical energy storage," \#1 in cluster analysis, covers energy storage literature related to low-carbon power flexibility. Power systems with high RE permeability need proportional energy storage capacity to meet system flexibility, which is the capability to balance residual load [64]. When configuring energy storage capacity for high-permeability RE generation systems, three main challenges need to be addressed: (a) intermittent energy supply, (b) site specificity (or spatial variability), and (c) prediction errors of RE generation.

Considering the requirement of reliability of any power system and the costs and benefits of optional energy storage technology $[65,66]$, the demand matching of RE generation capacity to energy storage capacity for RE simulation operation has emerged as a new hot spot [67]. It should also be recognized that the energy storage device plays a positive role in ensuring the reliability of the power grid and the economic operation of low-carbon generator sets. Establishing a reasonable price compensation mechanism for the auxiliary service provided by the energy storage device will moderate the negative impact on the investment decisions of the energy storage device [68,69].

The \#2 cluster collates the literature on " $\mathrm{CO}_{2}$ emission" of energy systems. This cluster represents the driving elements of energy-related carbon emission for the national and regional development of low-carbon energy policies. Idly used evaluation methods are LMDI (log-average Divisia index) [35,70,71].

Cluster \#3 focuses on the "multi-scope electricity-related carbon emissions accounting" to examine economic growth and the relation between energy consumption and $\mathrm{CO}_{2}$ discharges. The IPCC emission accounting method-the network method of simulating cross-regional current and the input-output model of environmental expansion-is adopted for the regional accounting of electricity-related carbon emissions [72]. Through the Kaya-LMDI method, the driving force of carbon emissions generated by energy consumption in China is analyzed. In China, economic activities represent the biggest impetus for the increase in $\mathrm{CO}_{2}$ discharges [71]. Therefore, optimizing the energy structure system, especially increasing the penetration of RE, is conducive to the realization of discharge decrease targets in the power sector. 
The representative papers in cluster \#4, "Energy system," are Mavromatidis et al. [73] and Gabrielli et al. [74]. Based on end-use energy demand, they studied the optimum plan of distributed energy systems and multi-energy systems with seasonal storage, respectively.

\subsection{Research Hotspots}

The key words of the 1419 papers were extracted and a clustering network of keywords, according to their occurrence frequency, was visualized using the CiteSpace timeline. The clustering network showed the clustering from left to right along a horizontal timeline (Figure 6). The modularity of this network is 0.6944 and the mean silhouettes are 0.8924 . This indicates that the research direction of low-carbon power systems is clearly defined, according to the agglomeration cluster. The index words extracted from the keywords are the cluster names marked by the LLR algorithm and arranged vertically in descending size order. The curve represents the association links among the clusters. Seven main clusters were generated in the hybrid network. The timeline overview shows that the duration of the research hotspot varies from one cluster to another, which represents the evolution of the research topic.

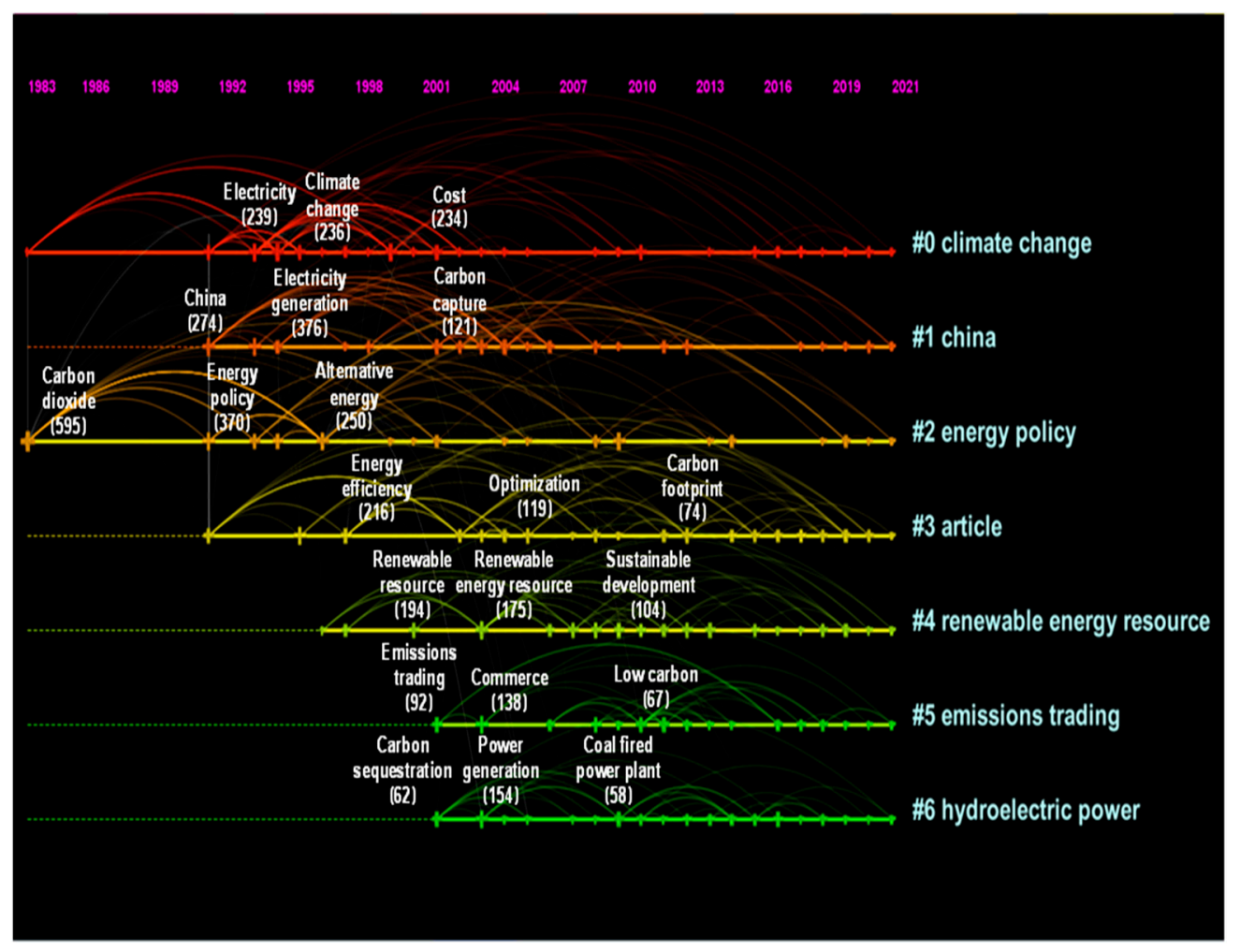

Figure 6. Clusters with timeline view of key words.

Ranking the keywords with the highest frequency in clustering, the following research hotspots were obtained:

- (\#0) Climate change. In this cluster, electricity, climate change, and cost are the three keywords with the highest frequency of occurrence, among which the research topic of electricity appears the earliest. With the deepening of the research, the relationship between power system and climate change gradually begins to increase;

- (\#1) China. As a major carbon emitter, the Chinese government recently announced to the world its ambition to achieve a double carbon goal. Currently, 70\% of China's electricity is supplied by thermal power units, which are highly dependent on fossil fuels and a major source of $\mathrm{CO}_{2}$ emissions. Implementing CCS technology is one overall consideration of energy supply security and $\mathrm{CO}_{2}$ emission reduction targets. The phasing out of thermal power units will be completed gradually and the share 
of RE in the energy supply structure will be increased. There is also a real need for China to establish a sustainable energy supply system [3,12];

- (\#2) Energy policy. As different countries pay more and more attention to the environmental impact of $\mathrm{CO}_{2}$ emissions from fossil fuel combustion, $\mathrm{RE}$ has become the most promising alternative energy [13], and the transition to sustainable energy systems is a thorny issue for many governments. Effective environmental policies, or a combination of policies and strategies, can contribute to a country's energy transition. Concerns about energy policy will persist as targets are set for a worldwide shift to low-carbon electricity based on renewables;

- (\#3) Energy conservation. According to the LLR algorithm, the \# 3 cluster is named "article" according to the LLR score. In order to avoid ambiguity in readers' understanding of the meaning of the cluster name, we take the "energy conservation" under the cluster LLR score second only to "article" as the cluster name. \#3 clustering describes the research hotspots in energy consumption and energy use efficiency. The coupling analysis of carbon emissions, economic growth, and energy consumption shows that they have a common growth trend. Those governments that need to address economic growth and reduce carbon emissions simultaneously need to concentrate on advancing energy utilization efficiency, implementing demand management, and minimizing carbon emissions in the process of energy use [75]. Like carbon emissions accounting, a carbon footprint is also employed to gauge the effect of human efforts on climate change. Quantitative analyses based on a carbon footprint not only explore the concentration and intensity of carbon emissions, but also provide a basis for the adoption of control measures and environmental supervision [76];

- (\#4, \#6) RE resource. We merged the \#4 and \#6 clusters, which together describe the topic of RE resource. There is no doubt that the research area of low-carbon energy production is focusing more and more on the utilization of RE. Many countries and regions have set the target of RE with high permeability within the power structure in future. However, due to the consideration of energy supply security and the economy of power supply, further research is still needed on this topic;

- (\#5) Emission trading. Under this clustering topic, the highest frequency keyword is "commerce." Research on the relationship between trade and environmental pollution points out that there is a positive or negative causal relationship between the growth of trade volume and environmental pollution, depending on whether the goods produced by the country belong to the energy-intensive production sector [77]. The carbon emissions trading system, as a policy measure to control $\mathrm{CO}_{2}$ emissions, is of great significance for those production departments that cannot fully achieve low-carbon operation. With the help of the design of the trading mechanism of the carbon market, we can achieve a cross-regional and cross-departmental ecological compensation coordination mechanism, a total quota trading mechanism, and use price means (carbon price) to guide the industrial production sector to carry out technological change and energy structure optimization [78].

\section{Conclusions}

This study used CiteSpace to perform a bibliometric analysis of developments in the research area of low-carbon energy production, based on 1419 articles retrieved from Scopus. Based on our analysis, some useful conclusions can be drawn: During the past 33 years, 1419 journal articles related to low-carbon energy production have been published. In 2021, 205 papers were published from January to April alone, indicating the increasing importance attached to this area of research. China and the United States are the two largest contributors to national publications, with China taking the lead in the number of publications; however, the United States leads in terms of academic influence. The growing interest of developing countries in adapting to climate change and environmental protection is reflected in the number of publications, with ten developing countries in the top 30 countries in terms of national productivity. Among the top 10 most productive 
authors in only this research field, five are from China. China's research output is excellent in terms of national productivity and author productivity, but its impact on global research trends is more limited due to its high output and low citation rates.

According to the statistical results of journal sources, 1419 articles on low-carbon energy production research were published in 143 journals. The top 15 most influential journals were evaluated in terms of productivity efficiency and SJR indicators. A total of 979 articles have been published in these journals, accounting for $68.99 \%$ of the total number of articles in 143 journals. This indicates that publications in the field of lowcarbon energy production are concentrated in these top journals. Energy Policy is the most productive journal, with 342 publication records. According to the SJR indicator, which reflects the impact of journals, Nature Energy tops the list with 19.635, all of which are at the heart of research that has a significant impact on low-carbon energy production research.

In accordance with the research hotspots, we found that the topic of "RE resource" is the main direction that scholars focus on in this field, and the optimal layout of power storage capacity to meet the flexibility of power system is also a prevalent direction. In addition, the energy policy effects related to the development of low-carbon power also have key effects on the low-carbon power system and the evaluation of the mechanism of environmental policies or a combination of policies and strategies will contribute to the energy transformation of the country. In recent years, as countries around the world set their own Net zero emission targets to control the total amount of GHG emissions. However, when carrying out the transformation of low-carbon energy, countries should, based on the concept of sustainable development, consider the development model of low-carbon power from the three aspects of economy, environmental protection and safety, and strengthen the linkage between the supply and the demand side.

This article reviews the progress and trends of global low-carbon energy research with the help of scientific bibliometric methods, however, there are some limitations of this research. First, the analysis data in this article comes from the Scopus database, which may lead to incomplete literature data. Thus, it is suggested that future research should discuss other platform databases, such as Web of Science and Google Scholar; secondly, comprehensive retrieval and data selection has always been the focus of the literature metrology method. However, the research on low-carbon energy systems involves interdisciplinary research on energy and environment, economics, sociology, and other disciplines. Although we have checked the relevant literature in advance to cover all the subject terms related to low-carbon energy as much as possible. However, omissions are inevitable in the literature search process. Finally, when using CiteSpace software, the findings may be a bit of different because of the choice of standardized approaches and parameter settings. In general, the research results of this article are objective, and offer more viewpoints for a complete grasp of the development of low-carbon power research.

The diversification and low-carbon development of energy resources is an irreversible trend. To accomplish the strategic goal of limiting global climate warming to $1.5^{\circ} \mathrm{C}$, at least $70-85 \%$ of the global electricity supply in 2050 will be provided by renewable energy [1]. However, in order to realize the energy transformation based on renewable energy in emerging economies, more attention should be paid to the carbon emission control of the household sector. According to the previous literature research, it is found that the carbon emission control of the power supply sector can be achieved by increasing the investment in renewable energy facilities. The household sector, as the largest energy consumption sector, the realization of low-carbon transition often involves more complex factors. Previous studies have mostly analyzed the influencing factors of the household sector in developed economies. However, there is still a relative lack of research on the influencing factors of consumer acceptance of renewable energy in emerging economies, so it is necessary to conduct specific research in this area in the future. It is especially necessary for a country like China, which implements electricity market regulation and has great differences in resource endowments. To establish a reasonable price guidance 
mechanism, policy guarantee mechanism and improve the efficiency of renewable energy will be one of the main directions of future research.

Author Contributions: All the authors made contribution to this paper. X.-C.M. conducted bibliometric analysis. Y.-H.S. reviewed the related literature. M.-K.L. explained the results and policy implications. All authors have read and agreed to the published version of the manuscript.

Funding: This research was supported by the Developing and Supporting Program for Science and Technology Policy Human Resource funded by the Ministry of Science and ICT.

Institutional Review Board Statement: Not applicable.

Informed Consent Statement: Not applicable.

Data Availability Statement: Not applicable.

Conflicts of Interest: The authors declare no conflict of interest.

\section{References}

1. IPCC. Global Warming of $1.5^{\circ} \mathrm{C}$. An IPCC Special Report on the Impacts of Global Warming of $1.5^{\circ} \mathrm{C}$ above Pre-Industrial Levels and Related Global Greenhouse Gas Emission Pathways, in the Context of Strengthening the Global Response to the Threat of Climate Change, Sustainable Development, and Efforts to Eradicate Poverty; Masson-Delmotte, V.P., Zhai, H.-O., Pörtner, D., Roberts, J., Skea, P.R., Shukla, A., Pirani, W., Moufouma-Okia, C., Péan, R., Pidcock, S., et al., Eds.; IPCC, 2018; in press. Available online: https:/ / www.ipcc.ch/sr15/ (accessed on 7 May 2021).

2. IEA (International Energy Association). Power Systems in Transition; IEA, 2020. Available online: https://www.iea.org/reports/ power-systems-in-transition (accessed on 7 May 2021).

3. Alvik, S.; Bakken, B.E.; Onur, O.; Horschig, H.; Koefoed, A.L.; McConnel, E.; Rinaldo, M.; Shafiei, E.; Zwarts, R.J. Energy Transition Outlook 2020-A Global and Regional Forecast to 2050; DNV GL: Hovik, Norway, 2020.

4. Reister, D.B.; Laurmann, J.A. Future $\mathrm{CO}_{2}$ emissions from combustion of natural and synthetic gases. Energy 1985, 10, 1043-1049. [CrossRef]

5. Busch, J.F.; Krause, F.L. Environmental externality surcharges in power system planning: A case study of New England. IEEE Trans. Power Syst. 1993, 8, 789-795. [CrossRef]

6. Okken, P.A. Storage restrictions and the preference for $\mathrm{CO}_{2}$ removal options. Energy Convers. Manag. 1993, 34, 823-831. [CrossRef]

7. Tabors, R.D.; Monroe, B.L. Planning for future uncertainties in electric power generation: An analysis of transitional strategies for reduction of carbon and sulfur emissions. IEEE Trans. Power Syst. 1991, 6, 1500-1507. [CrossRef]

8. Zongxin, W.; Zhihong, W. Policies to promote energy conservation in China. Energy Policy 1991, 19, 934-939. [CrossRef]

9. Liu, H.; Brown, T.; Andresen, G.B.; Schlachtberger, D.P.; Greiner, M. The role of hydro power, storage and transmission in the decarbonization of the Chinese power system. Appl. Energy 2019, 239, 1308-1321. [CrossRef]

10. Prasad, M.; Munch, S. State-level renewable electricity policies and reductions in carbon emissions. Energy Policy 2012, 45, 237-242. [CrossRef]

11. Audoly, R.; Vogt-Schilb, A.; Guivarch, C.; Pfeiffer, A. Pathways toward zero-carbon electricity required for climate stabilization. Appl. Energy 2018, 225, 884-901. [CrossRef]

12. Hoffmann, B.S.; Szklo, A. Integrated gasification combined cycle and carbon capture: A risky option to mitigate $\mathrm{CO}_{2}$ emissions of coal-fired power plants. Appl. Energy 2011, 88, 3917-3929. [CrossRef]

13. Liu, T.; Xu, G.; Cai, P.; Tian, L.; Huang, Q. Development forecast of renewable energy power generation in China and its influence on the GHG control strategy of the country. Renew. Energy 2011, 36, 1284-1292. [CrossRef]

14. UK Becomes First Major Economy to Pass Net Zero Emissions Law [EB/OL]. GOV.UK; 9 July 2021. Available online: https: //www.gov.uk/government/news/uk-becomes-first-major-economy-to-pass-net-zero-emissions-law (accessed on 29 July 2021).

15. Federal Climate Change Act-BMU-Laws [EB/OL]. bmu.de; 9 July 2021. Available online: https://www.bmu.de/GE838-1 (accessed on 29 July 2021).

16. 'Enhance Solidarity' to Fight COVID-19, Chinese President Urges, also Pledges Carbon Neutrality by 2060 [EB/OL]. UN News. 22 September 2020. Available online: https:/ / news.un.org/en/story/2020/09/1073052 (accessed on 29 July 2021).

17. Dominko, M.; Verbič, M. The economics of subjective well-being: A bibliometric analysis. J. Happiness Stud. 2019, 20, 1973-1994. [CrossRef]

18. Ellegaard, O.; Wallin, J.A. The bibliometric analysis of scholarly production: How great is the impact? Scientometrics 2015, 105, 1809-1831. [CrossRef] [PubMed]

19. Primc, K.; Dominko, M.; Slabe-Erker, R. 30 years of energy and fuel poverty research: A retrospective analysis and future trends. J. Clean. Prod. 2021, 301, 127003. [CrossRef]

20. Wang, L.; Wei, Y.; Brown, M.A. Global transition to low-carbon electricity: A bibliometric analysis. Appl. Energy 2017, 205, 57-68. [CrossRef] 
21. Yu, H.; Wei, Y.; Tang, B.; Mi, Z.; Pan, S. Assessment on the research trend of low-carbon energy technology investment: A bibliometric analysis. Appl. Energy 2016, 184, 960-970. [CrossRef]

22. Höhne, N.; Kuramochi, T.; Warnecke, C.; Röser, F.; Fekete, H.; Hagemann, M.; Day, T.; Tewari, R.; Kurdziel, M.; Sterl, S. The Paris Agreement: Resolving the inconsistency between global goals and national contributions. Clim. Policy 2017, 17, 16-32. [CrossRef]

23. Kinney, A.L. National scientific facilities and their science impact on nonbiomedical research. Proc. Natl. Acad. Sci. USA 2007, 104, 17943-17947. [CrossRef] [PubMed]

24. Falagas, M.E.; Pitsouni, E.I.; Malietzis, G.A.; Pappas, G. Comparison of PubMed, Scopus, web of science, and Google scholar: Strengths and weaknesses. FASEB J. 2008, 22, 338-342. [CrossRef]

25. Chen, C. A glimpse of the first eight months of the covid-19 literature on microsoft academic graph: Themes, citation contexts, and uncertainties. Front. Res. Metr. Anal. 2020, 5, 24. [CrossRef]

26. Mirumachi, N.; Sawas, A.; Workman, M. Unveiling the security concerns of low carbon development: Climate security analysis of the undesirable and unintended effects of mitigation and adaptation. Clim. Dev. 2020, 12, 97-109. [CrossRef]

27. Wang, N.; Chang, Y. The evolution of low-carbon development strategies in China. Energy 2014, 68, 61-70. [CrossRef]

28. Urban, F.; Nordensvärd, J. Low Carbon Development: Origins, Concepts and Key Issues; Routledge, 2013; pp. 25-44. Available online: https: / / www.taylorfrancis.com/chapters/edit/10.4324/9780203108628-11/low-carbon-development-origins-conceptskey-issues-frauke-urban-johan-nordensv\%C3\%A4rd?context=ubx\&refId=4020267c-2726-4549-9cc1-952e387071cb (accessed on 17 May 2021).

29. Geels, F.W.; Berkhout, F.; van Vuuren, D.P. Bridging analytical approaches for low-carbon transitions. Nat. Clim. Chang. 2016, 6, 576-583. [CrossRef]

30. Hannon, M.J.; Foxon, T.J.; Gale, W.F. The co-evolutionary relationship between energy service companies and the UK energy system: Implications for a low-carbon transition. Energy Policy 2013, 61, 1031-1045. [CrossRef]

31. Cheng, Y.; Zhang, N.; Kirschen, D.S.; Huang, W.; Kang, C. Planning multiple energy systems for low-carbon districts with high penetration of renewable energy: An empirical study in China. Appl. Energy 2020, 261, 114390. [CrossRef]

32. Liang, Q.; Fan, Y.; Wei, Y. The effect of energy end-use efficiency improvement on China's energy use and $\mathrm{CO}_{2}$ emissions: A CGE model-based analysis. Energy Effic. 2009, 2, 243-262. [CrossRef]

33. Lin, B.; Jia, Z. Economic, energy and environmental impact of coal-to-electricity policy in China: A dynamic recursive CGE study. Sci. Total Environ. 2020, 698, 134241. [CrossRef] [PubMed]

34. Xu, Y.; Yang, K.; Yuan, J. China's power transition under the global $1.5^{\circ} \mathrm{C}$ target: Preliminary feasibility study and prospect. Environ. Sci. Pollut. Res. 2020, 1-17. [CrossRef] [PubMed]

35. Ang, B.W.; Su, B. Carbon emission intensity in electricity production: A global analysis. Energy Policy 2016, 94, 56-63. [CrossRef]

36. Wang, L.; Chen, W.; Zhang, H.; Ma, D. Dynamic equity carbon permit allocation scheme to limit global warming to two degrees. Mitig. Adapt. Strat. Glob. Chang. 2017, 22, 609-628. [CrossRef]

37. O’Neill, B.C.; Kriegler, E.; Ebi, K.L.; Kemp-Benedict, E.; Riahi, K.; Rothman, D.S.; van Ruijven, B.J.; van Vuuren, D.P.; Birkmann, J.; Kok, K.; et al. The roads ahead: Narratives for shared socioeconomic pathways describing world futures in the 21 st century. Glob. Environ. Chang. 2017, 42, 169-180. [CrossRef]

38. Riahi, K.; Kriegler, E.; Johnson, N.; Bertram, C.; den Elzen, M.; Eom, J.; Schaeffer, M.; Edmonds, J.; Isaac, M.; Krey, V.; et al. Locked into Copenhagen pledges-Implications of short-term emission targets for the cost and feasibility of long-term climate goals. Technol. Forecast. Soc. Chang. 2015, 90, 8-23. [CrossRef]

39. Rogelj, J.; Luderer, G.; Pietzcker, R.C.; Kriegler, E.; Schaeffer, M.; Krey, V.; Riahi, K. Energy system transformations for limiting end-of-century warming to below 1.5 C. Nat. Clim. Chang. 2015, 5, 519-527. [CrossRef]

40. Ren, J.; Sovacool, B.K. Prioritizing low-carbon energy sources to enhance China's energy security. Energy Convers. Manag. 2015, 92, 129-136. [CrossRef]

41. Cheng, B.; Dai, H.; Wang, P.; Xie, Y.; Chen, L.; Zhao, D.; Masui, T. Impacts of low-carbon power policy on carbon mitigation in Guangdong Province, China. Energy Policy 2016, 88, 515-527. [CrossRef]

42. Small, H. Co-citation in the scientific literature: A new measure of the relationship between documents. J. Am. Soc. Inf. Sci. 1973, 42, 676-684. [CrossRef]

43. Zhang, J.; Jiang, L.; Liu, Z.; Li, Y.; Liu, K.; Fang, R.; Li, H.; Qu, Z.; Liu, C.; Li, F. A bibliometric and visual analysis of indoor occupation environmental health risks: Development, hotspots and trend directions. J. Clean. Prod. 2021, 300, 126824. [CrossRef]

44. Wang, H.; Ang, B.W.; Su, B. Assessing drivers of economy-wide energy use and emissions: IDA versus SDA. Energy Policy 2017, 107, 585-599. [CrossRef]

45. Ang, B.W. LMDI decomposition approach: A guide for implementation. Energy Policy 2015, 86, 233-238. [CrossRef]

46. Karmellos, M.; Kopidou, D.; Diakoulaki, D. A decomposition analysis of the driving factors of $\mathrm{CO}_{2}($ Carbon dioxide) emissions from the power sector in the European Union countries. Energy 2016, 94, 680-692. [CrossRef]

47. Yang, L.; Lin, B. Carbon dioxide-emission in China's power industry: Evidence and policy implications. Renew. Sustain. Energy Rev. 2016, 60, 258-267. [CrossRef]

48. Liu, Z.; Guan, D.; Wei, W.; Davis, S.J.; Ciais, P.; Bai, J.; Peng, S.; Zhang, Q.; Hubacek, K.; Marland, G. Reduced carbon emission estimates from fossil fuel combustion and cement production in China. Nature 2015, 524, 335-338. [CrossRef]

49. Lund, P.D.; Lindgren, J.; Mikkola, J.; Salpakari, J. Review of energy system flexibility measures to enable high levels of variable renewable electricity. Renew. Sustain. Energy Rev. 2015, 45, 785-807. [CrossRef] 
50. Ferreira, H.L.; Garde, R.; Fulli, G.; Kling, W.; Lopes, J.P. Characterisation of electrical energy storage technologies. Energy 2013, 53, 288-298. [CrossRef]

51. Flores-Quiroz, A.; Strunz, K. A distributed computing framework for multi-stage stochastic planning of renewable power systems with energy storage as flexibility option. Appl. Energy 2021, 291, 116736. [CrossRef]

52. Pimm, A.J.; Palczewski, J.; Barbour, E.R.; Cockerill, T.T. Using electricity storage to reduce greenhouse gas emissions. Appl. Energy 2021, 282, 116199. [CrossRef]

53. Safaei, H.; Keith, D.W. How much bulk energy storage is needed to decarbonize electricity? Energy Environ. Sci. 2015, 8, 3409-3417. [CrossRef]

54. Pfenninger, S.; Staffell, I. Long-term patterns of European PV output using 30 years of validated hourly reanalysis and satellite data. Energy 2016, 114, 1251-1265. [CrossRef]

55. Staffell, I.; Pfenninger, S. Using bias-corrected reanalysis to simulate current and future wind power output. Energy 2016, 114, 1224-1239. [CrossRef]

56. Brouwer, A.S.; van den Broek, M.; Zappa, W.; Turkenburg, W.C.; Faaij, A. Least-cost options for integrating intermittent renewables in low-carbon power systems. Appl. Energy 2016, 161, 48-74. [CrossRef]

57. Cheng, R.; Xu, Z.; Liu, P.; Wang, Z.; Li, Z.; Jones, I. A multi-region optimization planning model for China's power sector. Appl. Energy 2015, 137, 413-426. [CrossRef]

58. Gerbaulet, C.; von Hirschhausen, C.; Kemfert, C.; Lorenz, C.; Oei, P. European electricity sector decarbonization under different levels of foresight. Renew. Energy 2019, 141, 973-987. [CrossRef]

59. Louis, J.; Allard, S.; Kotrotsou, F.; Debusschere, V. A multi-objective approach to the prospective development of the European power system by 2050. Energy 2020, 191, 116539. [CrossRef]

60. Zappa, W.; Junginger, M.; van den Broek, M. Is a 100\% renewable European power system feasible by 2050? Appl. Energy 2019, 233-234, 1027-1050. [CrossRef]

61. Mikulčić, H.; Skov, I.R.; Dominković, D.F.; Alwi, S.R.W.; Manan, Z.A.; Tan, R.; Duić, N.; Mohamad, S.N.H.; Wang, X. Flexible carbon capture and utilization technologies in future energy systems and the utilization pathways of captured $\mathrm{CO}_{2}$. Renew. Sustain. Energy Rev. 2019, 114, 109338. [CrossRef]

62. Victoria, M.; Zhu, K.; Brown, T.; Andresen, G.B.; Greiner, M. The role of storage technologies throughout the decarbonisation of the sector-coupled European energy system. Energy Convers. Manag. 2019, 201, 111977. [CrossRef]

63. Capros, P.; Paroussos, L.; Fragkos, P.; Tsani, S.; Boitier, B.; Wagner, F.; Busch, S.; Resch, G.; Blesl, M.; Bollen, J. European decarbonisation pathways under alternative technological and policy choices: A multi-model analysis. Energy Strategy Rev. 2014, 2, 231-245. [CrossRef]

64. Haas, J.; Cebulla, F.; Cao, K.; Nowak, W.; Palma-Behnke, R.; Rahmann, C.; Mancarella, P. Challenges and trends of energy storage expansion planning for flexibility provision in low-carbon power systems-A review. Renew. Sustain. Energy Rev. 2017, 80, 603-619. [CrossRef]

65. Brouwer, A.S.; van den Broek, M.; Seebregts, A.; Faaij, A. Operational flexibility and economics of power plants in future low-carbon power systems. Appl. Energy 2015, 156, 107-128. [CrossRef]

66. Gils, H.C.; Simon, S. Carbon neutral archipelago-100\% renewable energy supply for the Canary Islands. Appl. Energy 2017, 188, 342-355. [CrossRef]

67. Schlachtberger, D.P.; Brown, T.; Schäfer, M.; Schramm, S.; Greiner, M. Cost optimal scenarios of a future highly renewable European electricity system: Exploring the influence of weather data, cost parameters and policy constraints. Energy 2018, 163, 100-114. [CrossRef]

68. Haas, J.; Cebulla, F.; Nowak, W.; Rahmann, C.; Palma-Behnke, R. A multi-service approach for planning the optimal mix of energy storage technologies in a fully-renewable power supply. Energy Convers. Manag. 2018, 178, 355-368. [CrossRef]

69. Poletti, S.; Staffell, I. Understanding New Zealand's wind resources as a route to $100 \%$ renewable electricity. Renew. Energy 2021, 170, 449-461. [CrossRef]

70. Cárdenas, B.; Swinfen-Styles, L.; Rouse, J.; Hoskin, A.; Xu, W.; Garvey, S.D. Energy storage capacity vs. renewable penetration: A study for the UK. Renew. Energy 2021, 171, 849-867. [CrossRef]

71. Yang, J.; Cai, W.; Ma, M.; Li, L.; Liu, C.; Ma, X.; Li, L.; Chen, X. Driving forces of China's $\mathrm{CO}_{2}$ emissions from energy consumption based on Kaya-LMDI methods. Sci. Total Environ. 2020, 711, 134569. [CrossRef]

72. Wei, W.; Zhang, P.; Yao, M.; Xue, M.; Miao, J.; Liu, B.; Wang, F. Multi-scope electricity-related carbon emissions accounting: A case study of Shanghai. J. Clean. Prod. 2020, 252, 119789. [CrossRef]

73. Mavromatidis, G.; Orehounig, K.; Carmeliet, J. Uncertainty and global sensitivity analysis for the optimal design of distributed energy systems. Appl. Energy 2018, 214, 219-238. [CrossRef]

74. Gabrielli, P.; Gazzani, M.; Martelli, E.; Mazzotti, M. Optimal design of multi-energy systems with seasonal storage. Appl. Energy 2018, 219, 408-424. [CrossRef]

75. Wang, S.S.; Zhou, D.Q.; Zhou, P.; Wang, Q.W. $\mathrm{CO}_{2}$ emissions, energy consumption and economic growth in China: A panel data analysis. Energy Policy 2011, 39, 4870-4875. [CrossRef]

76. Shi, S.; Yin, J. Global research on carbon footprint: A scientometric review. Environ. Impact Assess. Rev. 2021, 89, 106571. [CrossRef] 
77. Dogan, E.; Seker, F. Determinants of $\mathrm{CO}_{2}$ emissions in the European Union: The role of renewable and non-renewable energy. Renew. Energy 2016, 94, 429-439. [CrossRef]

78. Cao, J.; Ho, M.S.; Jorgenson, D.W.; Nielsen, C.P. China's emissions trading system and an ETS-carbon tax hybrid. Energy Econ. 2019, 81, 741-753. [CrossRef] 